\title{
Potential benefits of renewable fuel cell systems for rural communities’ power supply
}

\author{
Doudou N. Luta ${ }^{1}$ and Atanda K. Raji ${ }^{2}$ \\ 1212123254@mycput.ac.za, rrajia@cput.ac.za \\ Faculty of Engineering, \\ Department of Electrical, Electronics and Computer Engineering, \\ Cape Peninsula University of Technology \\ Symphony Way, Bellville, Western Cape, South Africa
}

\begin{abstract}
Fuel cell systems are an emerging electric energy technology and provide significant benefits for our environment, health and development. Over the last decade, researches are being undertaken to bring the technologies into their commercial maturity. With their gaining interest, they show important opportunities in powering remote areas with no access to the power utility grid. In this paper, we explore potential environmental, social and economic benefits linked to this technology in supplying electric power to rural communities. A simulation case is presented for a decision-making between a stand-alone renewable fuel cell system and a grid extension.
\end{abstract}

Keywords: Fuel cells, hybrid power systems, photovoltaic systems, renewable energy.

\section{Introduction}

Electric energy supply in many countries is based on centralised power plants using either fossil fuels or nuclear reactants as primary energy. These plants are usually located far away from the main cities and require transmission and distribution networks to ensure that the power is delivered to the consumers. Concrete solutions need as well as to be found to provide power to rural communities, i.e. areas situated outside beyond cities without access to electricity. In Africa, such places are generally characterised by severe poverty and little development activities [1]. A report from the International Energy Agency has revealed that in 2014, 1.3 billion of people worldwide did not have access to electricity [2].

Researches have revealed that extending the existing electric networks to deliver power to these areas is economically and sometimes technically unfeasible. Stand-alone or off-grid power systems can in this case represent the best alternative compared to the construction on new power lines. These systems are able to supply electric energy to different applications in remote areas ranging from houses, community services, water pumping and purification systems, telecommunications, etc.

In an off-grid power system, the electricity can be supplied from an individual source or a combination of sources whether renewable for instance wind turbines, photovoltaic panels, and micro hydro, fuel cells, etc. or non-renewable (diesel generator). In countries like Russia, the electricity supply in remote areas relies on diesel generators. These systems impose an important economic and social burden on the local population, in addition to the environmental impact of

ACRID 2017, June 20-21, Victoria Falls, Zimbabwe

Copyright (C) 2017

DOI 10.4108/eai.20-6-2017.2270897 
greenhouse gas emissions, black carbon and oil spills [3]. As a consequence, renewable standalone systems are gaining interest and their use is becoming more significant.

Apart from the fact that renewable off-grid power systems are suitable in dealing with environmental conservation, they can as well provide more possibilities ranging from socioeconomic development to energy access as well as energy security; knowing that renewable energy technologies are decentralised, they offer more opportunities in terms of job creation, and contributes in reducing poverty, allowing access to better education as well as better health.

Stand-alone power systems in this case refer to remote areas power supply, i.e. as a small electricity network serving a single property owner with very simple loads or several communities with complex and interconnected power stations [2]. Remote area power supply technologies can be grouped into three categories based on energy resources used [2]:

- single energy resource based remote areas power supply systems,

- hybrid remote areas power supply systems,

- remote areas power supply systems with storage systems.

Fig. 1 and Fig. 2 show a single energy resource and a hybrid remote area power supply respectively.

Among the three categories mentioned above, renewable single resource remote areas power supply is the most unreliable system because of the intermittency and variability of renewable resources, using a hybrid configuration can improve the system efficiency since the energy supply depends at least on two sources, adding an energy storage to a hybrid system can further increases the reliability as energy storage can reduce power fluctuations, enhances the system flexibility, and enables the storage and dispatching of the electricity generated [4]. This paper deals with a renewable based-remote area power supply using fuel cell systems, the objective is to show the potential benefits of such technologies for rural communities' power supply. A simulation case will be considered as well for decision-making between a standalone renewable fuel cell system and a potential grid extension.

The paper is structured as follows, the next section gives the layout and describes a typical renewable fuel cell system, the section 3 discuss about the potential benefits of renewable fuel cell systems when implemented in rural areas, the fourth section details a case study of a decision-making between the standalone system and the grid extension and the last section gives the conclusion.

\section{System layout and description}

A typical renewable fuel cell system layout is shown in Fig 3; the system consists of photovoltaic panels, a fuel cell stack and a storage system. Power Management Unit (PMU) enables the coordination between the different energy sources involved (PV panels electrolyzers and fuel cells). 


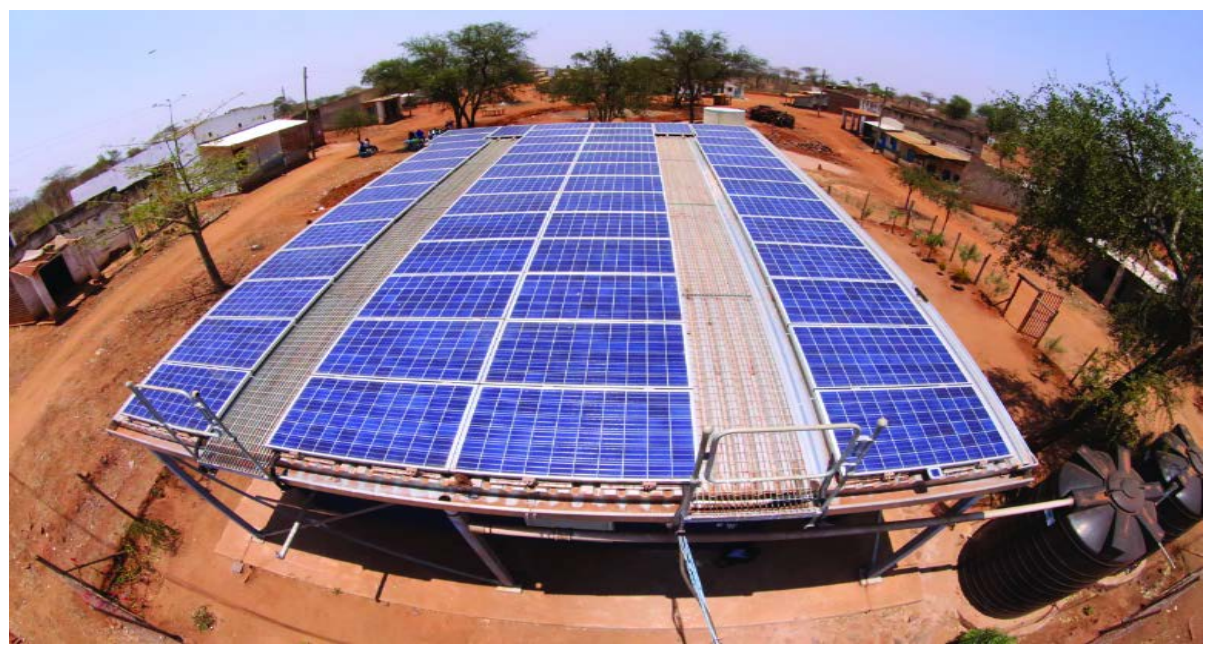

Fig. 1. Solar photovoltaic for power supply in a rural area in Africa [5]

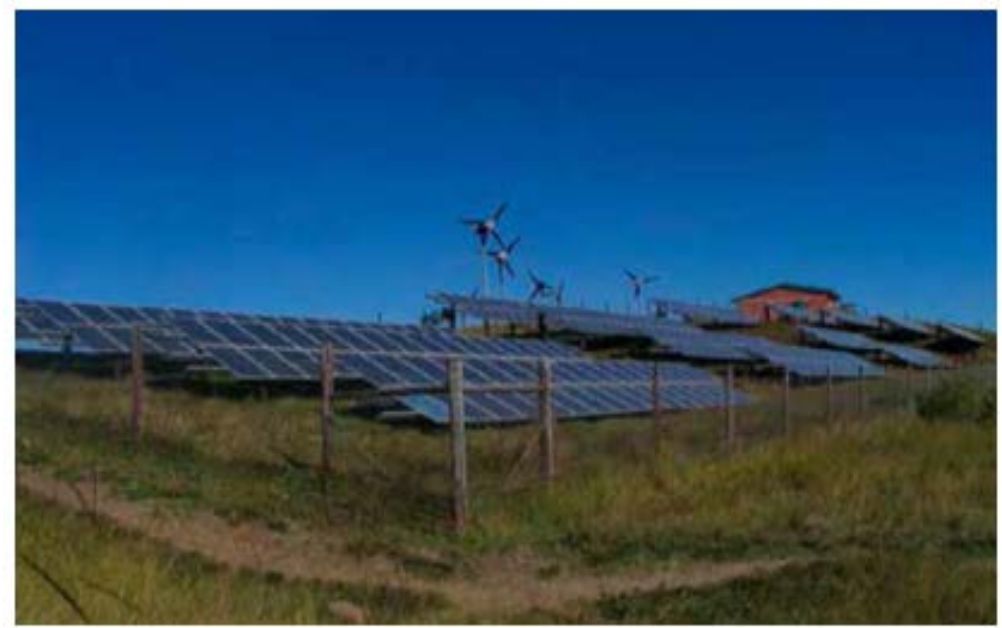

Fig. 2. Hybrid solar-wind mini-grid at Lucingweni Village in the Eastern Cape Province of South Africa

Generally, in such a system, PV panels work as a primary source; it converts solar irradiation into electricity provided to a DC bus. Hydrogen is used by the second working subsystem (the fuel cell stack) which produces electric energy to supply the DC bus. 


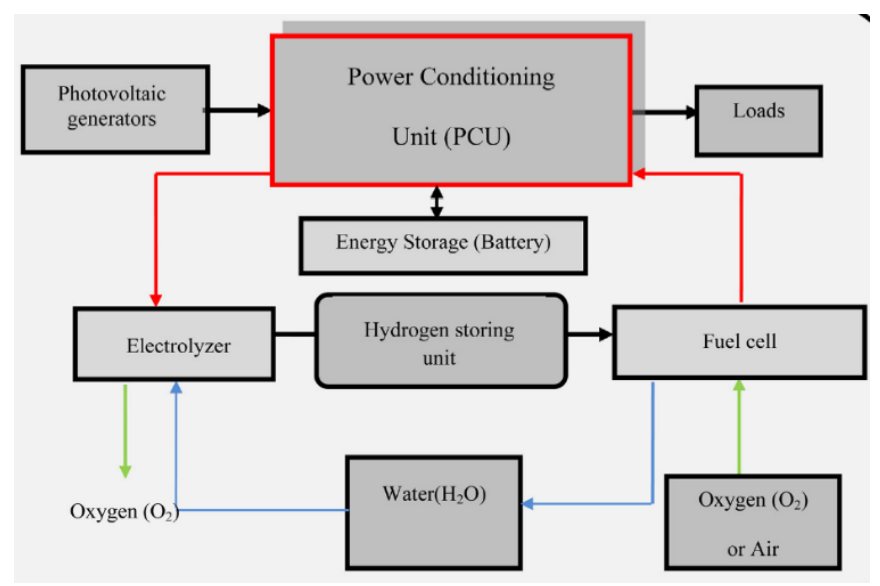

Fig. 3. Renewable fuel cell system layout [6]

A typical fuel cell is defined as an electro-chemical device converting chemical energy from an electrolytic reaction directly to electrical energy by rejecting heat and water [7], [8]. It is made up of a negatively charged electrode (anode), a positively charge electrode (cathode) and an electrolyte membrane (Fig. 4). At the anode, the hydrogen gas ionises realising electrons and creating $\mathrm{H}+$ as shown in equation (1), whereas at the cathode, oxygen reacts with electrons taken from the electrode, and $\mathrm{H}+$ from the electrolyte to form water (Equation (2))[9].

$$
\begin{aligned}
& 2 \mathrm{H}_{2} \rightarrow 4 \mathrm{H}^{+}+4 \mathrm{e}^{-} \\
& \mathrm{O}_{2}+4 \mathrm{e}^{-} \rightarrow 2 \mathrm{H}_{2} \mathrm{O}
\end{aligned}
$$

The overall reaction in a fuel cell producing water, heat (Qheat) and electricity (Wele) follows the equation (3) below [10]:

$$
\mathrm{H}_{2}+1 / 2 \mathrm{O}_{2}^{-} \rightarrow \mathrm{H}_{2} \mathrm{O}+\mathrm{W}_{\text {ele }}+Q_{\text {heat }}
$$

In a fuel cell, hydrogen is used as the principal fuel or reactant whereas oxygen is used as an oxidant, however, several different types of reactants such as ethanol or some fuels derived from biomass can as well be used depending upon the type of fuel cell technology; these fuel cell technologies can be classified according to the type of electrolytes used, The most current technologies include [11], [12]:

- Proton Exchange or Polymer Electrolytic Membrane Fuel Cell (PEMFC)

- (Operating temperature: $60-90^{\circ} \mathrm{C}$, Conversion efficiency: $50-60 \%$ )

- Phosphoric Acid Fuel Cell

- (Operating temperature: $180-200^{\circ} \mathrm{C}$, Conversion efficiency: 55\%)

- Alkaline Fuel Cell (AFC), Phosphoric Acid Fuel Cell (PAFC),

- (Operating temperature: $60-90^{\circ} \mathrm{C}$, Conversion efficiency: $50-60 \%$ )

- Molten Carbonate Fuel Cell (MCFC),

- (Operating temperature: $400-600^{\circ} \mathrm{C}$, Conversion efficiency: $60-65 \%$ )

- $\quad$ Solid Oxide Fuel Cell (SOFC),

- (Operating temperature: $800-1000^{\circ} \mathrm{C}$, Conversion efficiency: 50 - 65\%)

- Direct Methanol Fuel Cell (DMFC),

- (Operating temperature: $60-90^{\circ} \mathrm{C}$, Conversion efficiency: $50-60 \%$ ) 
The overall efficiency of fuel cell technologies can be further improved if the heat as byproducts is harness and used appropriately [13].

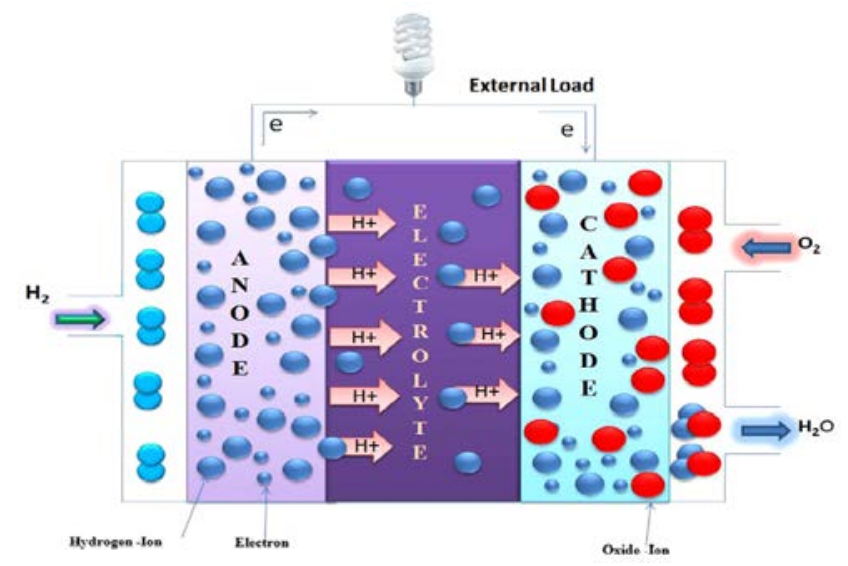

Fig.4. Fuel cell stack internal schematic [14]

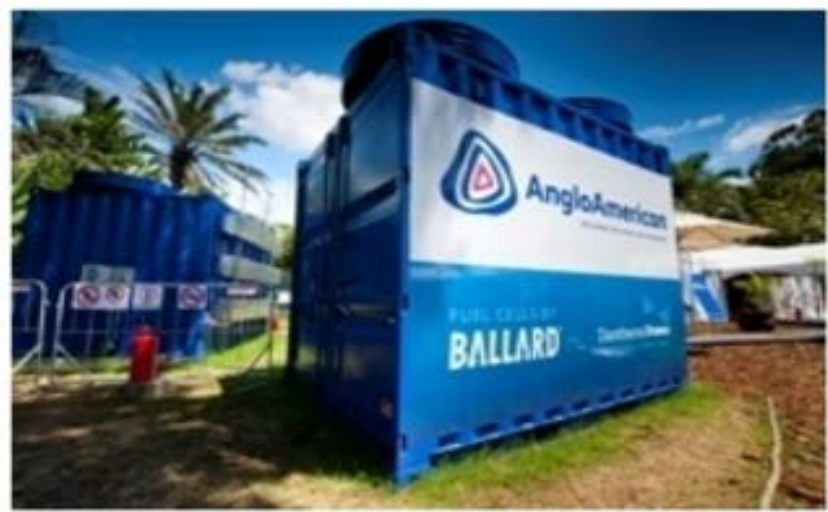

Fig.5. $150 \mathrm{~kg}$ fuel cell systems demonstrated at COP117 conference in South Africa [15]

Fig.5. shows a complete fuel cell system. Among the existing technologies mentioned above, PEMFC technologies are the most developed and popular systems powering around $90 \%$ of current existing fuel cell systems, followed by SOFC that have recently grown to reach $10 \%$ of sales in the world. [16]

There are a number on ways in which hydrogen can be produced, some are environmentally friendly, and others are not. Clean ways of hydrogen generation involve the use of electricity generated by renewable technologies such as solar, wind, tidal, biomass, etc. then in turn this electricity is used to produce hydrogen through electrolysis. The unclean methods of generating hydrogen use fossil fuel, oil, coal and natural gas which are taken and reformed to hydrogen, as a result, carbon dioxide is generated as by-products. In the same vein, nuclear power is as well used to produce hydrogen; however, the by-product for this process is toxic and radioactive waste. [17] In the considered architecture (See Fig. 4), hydrogen is produced from the 
electrolyser with the help of PV panels, however, researchers predict that in few years biomass or renewable organic matter such as forest residues and agricultural crops and wastes will power fuel cells [18].

In such a power system, battery energy storage can also be included to increase the system reliability and flexibility. Several types of rechargeable batteries exist in the market, among them; lead acid represents more than $90 \%$ of the whole market.

In rural communities, such systems present potential benefits ranging from improving public health and environmental quality, creating jobs and other economic benefits, providing combined heat and power, providing affordable energy prices, allowing capacity building and community empowerment and allowing innovation in products, practices and policies.

\section{Benefits of implementing renewable fuel cell systems}

Renewable fuel cell systems carry a combination of gains shown below [14]:

- Effectiveness: temperature represents an important parameter that dictates the efficiency of a heat engine. Fuel cells do not involve any combustion process and thus are free from such type of limitation. For this reason, these are highly efficient with respect to combustion engines.

- Pollutions free: fuel cells do not pollute our environment because they do not generate any contaminants. They produce water and heat as a by-product, which can be used for other purposes.

- Simplicity: fuel cells are very simple, reliable, and noiseless because their functioning is independent of any moving parts. They have long life, which can be as large as 40,000h. Furthermore, these can be stacked in modular form to match any power requirement.

In rural communities, renewable fuel cell systems present potential benefits ranging from improving public health and environmental quality, creating jobs and other economic benefits, providing combined heat and power, providing affordable energy prices, allowing capacity building and community empowerment and allowing innovation in products, practices and policies.

\subsection{Improving public health and environmental quality}

Like others clean energy technologies, renewable fuel cell systems propose significant public health benefits; the air and water polluted release by unclean energy sources is linked to health concerns such as breathing problems, neurological damage, heart attacks, and cancer. Clean energy technologies in general have been proven to reduce premature mortality and lost workdays.[19]

Fuel cell systems can as well the health hazard caused by uncontrolled use of biomass for heating and cooking.[13]

\subsection{Creating jobs and other economic benefits}

Although the total of jobs created directly are generally limited, these technologies offer jobs in operating and maintenance of the installation with a long-term impact on sustainability of rural communities. In addition, number of jobs can as well be created along the technology 
supply chain in construction, manufacturing, specialised services and in rural activities once the electricity becomes available, jobs can be created in farming, forest, etc.

\subsection{Providing Combined Heat and Power CHP}

CHP is defined as the generation of heat and power from a single fuel cell with the perspective of using both commodities [20]. Taking advantage of the fact that fuel cells generate heat alongside electricity. Heat can be recovered [13] and use for Heating Ventilation and Air Conditioning (HVAC) equipment, knowing that this equipment is one of the major consumers of electricity [21]; in South Africa for instance, 13\% of the energy produced is used for space heating whereas $32 \%$ for hot water [22].

\subsection{Providing Affordable and Stable Energy Prices}

Renewable energy technologies in general require an important upfront capital investment to be built, however, once built, they operate at low costs since the fuel used is free and always available, which is in contrast with fossil fuel; prices can vary dramatically and are prone to considerable swings.

\subsection{Allowing capacity building, community empowerment, innovation in products, practices and policies}

Energy in general plays an important role in the development of a society, as people are exposed to new realities, their capacities to learn and to innovate increase.

Rural areas connected to renewable energy installations such fuel cell systems or others can as well be affected and actively contribute to the communities by the developing new products, new technologies, and new policy approaches.

\section{Decision-making case study}

The selected site is Yangambi; a city in the northern east part of the Orientale Province of the Democratic Republic of Congo located at $0^{\circ} 48.4^{\prime} \mathrm{N}$ latitude and $24^{\circ} 27.2^{\prime} \mathrm{E}$ longitude [23]. Fig. 6 shows its satellite view. The city covers an area of $69 \mathrm{~km}^{2}$ with an estimated population of 35166 inhabitants. [24] The nearest power station capable of feeding the city's community load requirement is situated in Kisangani; a neighbourhood town 112 km away [25]. 


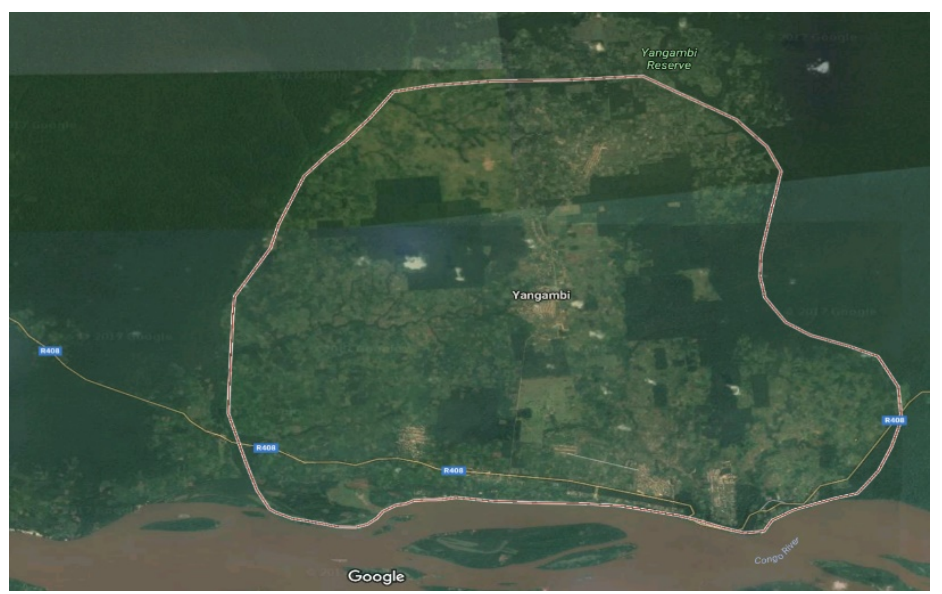

Fig. 6. View of the location [23]

In this study, a renewable based power system combining photovoltaic generators, fuel cells, an electrolyser and a hydrogen tank is simulated to determine the best feasible options between a standalone system and a grid extension. The simulation is performed using Homer Pro software for an estimated project lifetime of 25 years. The emphasis will be on comparing both systems cost by considering the capital, replacement, operation and maintenance costs as well as the interest.

\subsection{Site Load Requirement}

The site energy consumption is assumed to be a community load of a scaled annual average energy of $995 \mathrm{kWh}$ per day with a peak value of 120.07 kW. (See Fig. 7).

\section{Daily Profile}

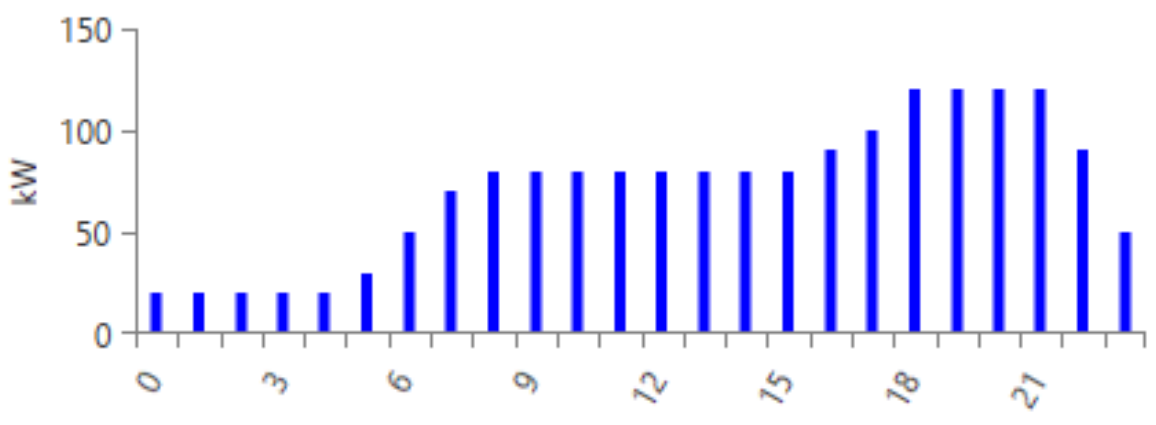

Fig. 7. Monthly average load for a year

\subsection{Solar Resources of the Location}

The solar resource for this location was taken from INSEL software meteorological monthly means weather data blocks [26] (See Fig. 8). The annual average solar global horizontal 
irradiance is shown to be $4.83 \mathrm{kWh} / \mathrm{m}^{2} /$ day whereas the clearness which refers to the fraction of the solar insolation transmitted through the atmosphere to strike the surface of the earth is 0.483 . These values indicate that the site has enough potential to deliver a considerable amount of power from a photovoltaic system.

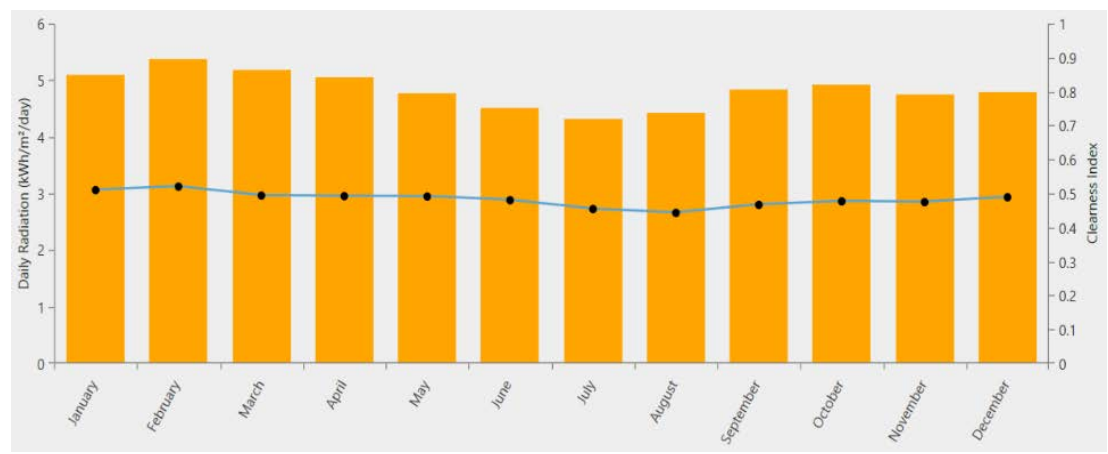

Fig. 8. Monthly average Solar Global Irradiance

\subsection{System Modelling}

Fig. 9 shows the HOMER model of the system designed by choosing suitable components and applying various constrained. In this case, the grid is used for extension purpose in order to choose between a standalone system and a grid extension which will be the optimal and cost effective to consider. With HOMER, the optimisation process implies selecting optimal values for decision variable (PV, fuel cells, converter, electrolyzer and hydrogen tank sizes).

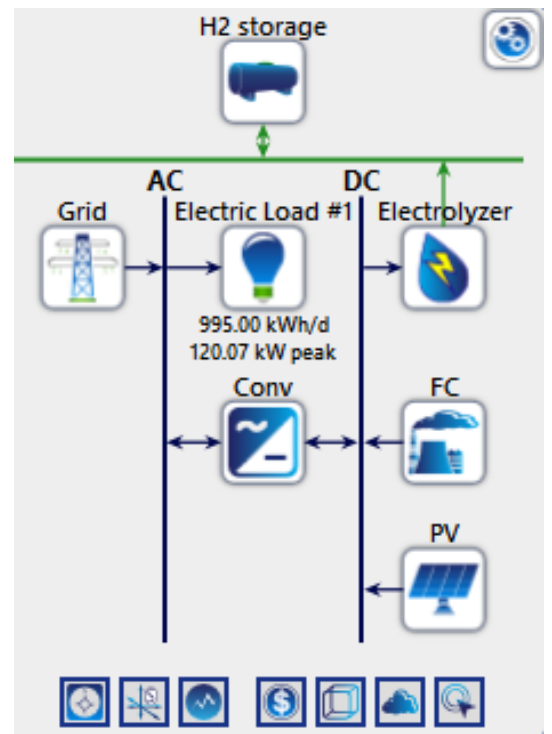

Fig. 9. HOMER PV-Fuel cell system model 
The model constraints inputs considered include $0 \%$ of the annual capacity shortage, $2 \%$ of the inflation rate and $8 \%$ of the discount rate. These values as well as the grid extension cost data are obtained from HOMER Pro as default values. More inputs data are given in tables 1, 2 and 3.

Table 1. PV-Fuel cell system search space data

\begin{tabular}{llll}
\hline \multicolumn{3}{c}{ PV-Fuel cell system search space input data } \\
\hline Components & Sizing options & Lifetime & Other information \\
\hline PV & Homer optimiser & 25 years & Derating factor: 70\% \\
Fuel Cell & $120 \mathrm{~kW}, 140 \mathrm{~kW}, 160 \mathrm{~kW}$, & 40000 & Min load ratio:1\% \\
& $200 \mathrm{~kW}$ & hours & Efficiency: 95\% \\
Converter & Homer optimiser & 20 years & Efficiency: 80\% \\
Electrolyzer & $200 \mathrm{~kW}, 400 \mathrm{~kW}, 600 \mathrm{~kW}$, & 15 years & Ef \\
& $700 \mathrm{~kW}, 800 \mathrm{~kW}$ & & \\
Hydrogen & $100 \mathrm{~kg}, 200 \mathrm{~kg}, 300 \mathrm{~kg}$, & 20 years & Relative tank size: $1 \%$ \\
\hline tank & $400 \mathrm{~kg}$ &
\end{tabular}

Table 2. Costs data [27-29]

\begin{tabular}{llll}
\hline & \multicolumn{3}{c}{ Costs input data } \\
\hline Components & Capital costs & $\begin{array}{l}\text { Replacement } \\
\text { cost }\end{array}$ & $\begin{array}{l}\text { Operation and Maintenance } \\
\text { costs }\end{array}$ \\
\hline PV & $\$ 1000$ per $1 \mathrm{~kW}$ & $\$ 750$ & $\$ 55$ per year \\
Fuel Cell & $\$ 4000$ per $1 \mathrm{~kW}$ & $\$ 3000$ & $\$ 0.01$ per hour per $\mathrm{kW}$ \\
Converter & $\$ 400$ per $1 \mathrm{~kW}$ & $\$ 300$ & $\$ 10$ per year \\
Electrolyzer & $\$ 1100$ per $10 \mathrm{~kW}$ & $\$ 825$ & $\$ 10$ per year \\
$\begin{array}{l}\text { Hydrogen } \\
\text { tank }\end{array}$ & $\$ 1000$ per $1 \mathrm{~kg}$ & $\$ 750$ & $\$ 10$ per year \\
\hline
\end{tabular}

Table 3. Grid extension costs data from HOMER Pro

\begin{tabular}{ll}
\hline \multicolumn{2}{c}{ Grid extension input data. } \\
\hline Capital costs $(\$ / \mathrm{km})$ & 8000 \\
Operation and maintenance costs (\$ per year per $\mathrm{km})$ & 160 \\
Grid energy price $(\$ / \mathrm{kWh})$ & 0.1 \\
\hline
\end{tabular}




\subsection{Simulation results}

The results for the optimised system in the chosen location with a scaled annual average energy requirement of $995 \mathrm{kWh}$ per day at $120.07 \mathrm{~kW}$ of peak loads are shown in table 4 . These results are obtained after several simulations by taking into consideration all the input data. In this context, for continuous energy supply throughout the year, the optimal standalone system should include a $5379 \mathrm{~kW}$ PV generator, a $140 \mathrm{~kW}$ fuel cell, a $156 \mathrm{~kW}$ converter, a $700 \mathrm{~kW}$ electrolyzer and a $200 \mathrm{~kg}$ of hydrogen capacity storage. The average electric energy production is shown in Fig. 10; $98.3 \%$ of the generation is provided by the PV whereas the fuel cell contributes for the remaining $1.71 \%$, making the overall fuel cell system (fuel cell, electrolyzer and hydrogen tank) to serve more as a storage; in normal operation, the PV generator supplies the load, any excess is used to feed the electrolyzer for hydrogen generation, whereas in the event that the PV generator is unable to meet the load requirement, the fuel cell system will feed the load.

The Total Net Present Cost of such a system is US\$10,629,270 with an initial capital and energy costs of US\$6,971,069.60 and US\$2.53 respectively. It can be seen from the results that the cost of energy is slightly higher than that from the grid (See tables 3 and 4) making the standalone system to look no viable, however, other factors such as the capacity shortage fraction which is the ratio of the annual capacity shortage over the annual electric load, the breakeven grid extension distance and the land use are examined as well.
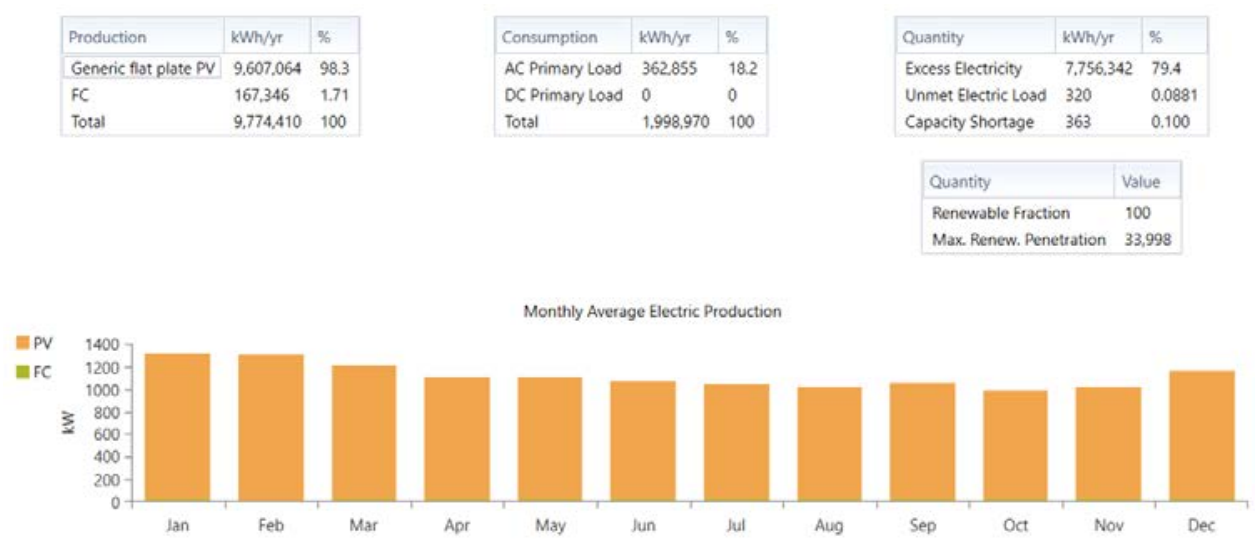

Fig. 10. Monthly average electric production

Table 4. Simulation results

\begin{tabular}{ll}
\hline \multicolumn{2}{c}{ Optimisation results } \\
\hline PV capacity (kW) & 5,379 \\
Fuel cell capacity $(\mathrm{kW})$ & 140 \\
Converter capacity (kW) & 156 \\
Electrolyzer (kW) & 700 \\
Hydrogen tank (kg) & 200 \\
Initial capital costs (US\$) & $6,971,069.60$ \\
Cost of energy (US\$/kWh) & 2.53 \\
Operating cost (US\$) & $315,899.10$
\end{tabular}




\begin{tabular}{ll} 
Operation and Maintenance costs (US\$) & $3,597,681.55$ \\
Replacement cost (US\$) & $487,200.01$ \\
Salvage (US\$) & $426,682.93$ \\
Total Net Present Cost (US\$) & $10,629,268.23$ \\
\hline
\end{tabular}

\subsection{Discussion}

Fig. 11 shows the Total Net Present Cost of the stand-alone power system as function of the grid extension distance. It can be noted that as the grid extension distance expands, the electrification cost with regard to the off-grid system remains unchanged whereas that of the grid extension increases making it to become no viable. Beyond 1,036.12 km which is the breakeven grid extension distance, the grid extension is more expensive than the implementation of a standalone power system.

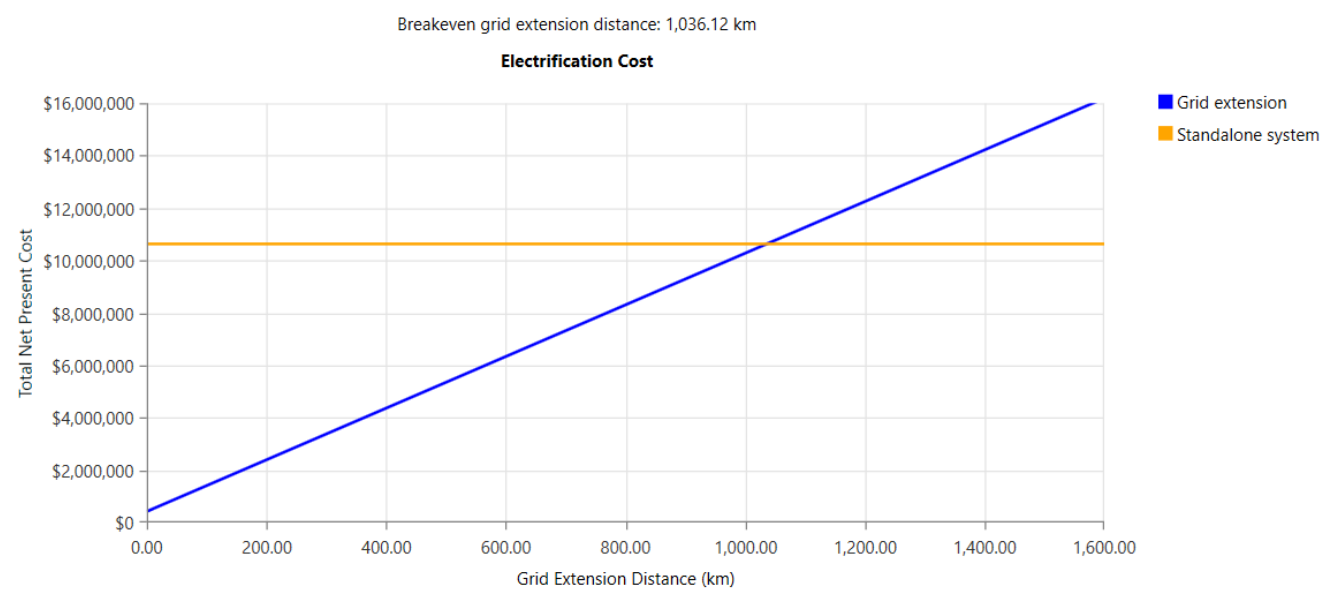

Fig. 11. Monthly average electric production

With respect to the considered site, the nearest power station capable of meeting city's community load requirement is located $112 \mathrm{~km}$ away from the site, making the choice of a grid extension more cost-effective option.

\section{Conclusions}

Renewable fuel cell systems carry a combination of benefits ranging from effective, pollution free and simple electric energy technologies. In this paper, we have shown the potential role that such a technology can play in empowering rural communities. These roles can be summarised as follows:

- $\quad$ improving public health and environmental quality,

- creating jobs and other economic benefits,

- $\quad$ providing combined heat and power,

- $\quad$ providing affordable energy prices, 
allowing capacity building and community empowerment, allowing innovation in products, practices and policies. A case study has shown that for the considered site, the grid extension is the best alternative compared to a stand-alone system.

\section{References}

[1] Gopaul, M.: The significance of Rural Areas in South Africa for Tourism. No. November, pp. 1-143 (2006)

[2] Tan, Y., Meegahapola, L., Muttaqi, K.M.: A review of technical challenges in planning and operation of remote area power supply systems. Renew. Sustain. Energy Rev. 38, pp. 876--889 (2004)

[3] Boute, A.: Off-grid renewable energy in remote Arctic areas: An analysis of the Russian Far East. Renew. Sustain. Energy Rev. 59, pp. 1029-1037 (2016)

[4] Amrouche, S.O., Rekioua, D., Rekioua, T.: Overview of energy storage in renewable energy systems. In: 3rd International Renewable and Sustainable Energy Conference (IRSEC), pp. 1-6. (2015)

[5] Transforming rural communities through mini-grids Smart Villages, http://e4sv.org/transforming-rural-communities-through-mini-grids/

[6] Rekioua, D., Bensmail, S., Bettar, N.: Development of hybrid photovoltaic-fuel cell system for stand-alone application. Int. J. Hydrogen Energy 39, no. 3, pp. 1604-1611 (2014)

[7] Barbir, F.: PEM Fuel Cell Theory and Practice. Elsevier Academic Press, (2005)

[8] Revankar, S., Majumdar, P.: Fuel Cells: Principles, Design and Analysis. CRC Press, (2014)

[9] Larminie, J., Dicks, A.: Fuel Cell Systems Explained. John Wiley \& Sons Ltd, (2003)

[10] Sharaf, O.Z., Orhan, M.F.: An overview of fuel cell technology: Fundamentals and applications. Renew. Sustain. Energy Rev. 32, pp. 810-853

[11] Hoogers, G.: Fuel Cell Technology Handbook. CRC Press, (2003)

[12] Vasquez, L.O..: Fuel Cell Research Trends. Nova Science Publisher Inc., New York, (2007)

[13] Raji, A.K., Kahn, M.T.E..: Can Fuel Cell Systems be efficient and effective as domestic distributed generation units? In: 21st Domestic Use of Energy Conference (DUE), IEEE Xplore, (2013)

[14] Raza, R., Akram, N., Javed, M.S., Rafique, A., Ullah, K., Ali, A., Saleem, M., Ahmed, R.: Fuel Cell Technology for sustainable development in Pakistan an Overview. Renew. Sustain. Energy Rev. 53, pp. 450-461, (2016)

[15] Fuel Cell advantage Ballard Power Systems, http://ballard.com/landingpages/Q_A.aspx

[16] Dodds, P.E., Staffell, I., Hawkes, A.D., Li, F., Grunewal, P., McDonald, W., Ekins, P.: Hydrogen and fuel cell technologies for heating: A review. Int. J. Hydrogen Energy. 40, no. 5, pp. 2065-2083, (2015)

[17] Harper, G.D.J.: Fuel Cell projects for the evil genius. The McGraw-Hill Companies, (2008)

[18] A future energy generation option for rural areas, http://www.neo.ne.gov/fall97/fall97_14.htm

[19] Machol, B., Rizk, S.: Economic value of U.S. fossil fuel electricity health impacts. Environ. Int. 52, pp. 75-80 (2013) 
[20] Elmer, T., Worall, M., Wu, S., Riffat, S.B. :Fuel cell technology for domestic built environment applications: State of-the-art review. Renew. Sustain. Energy Rev. 42, pp. 913931, (2015)

[21] Luta, D.N., Raji, A.K., Fritz, W.: Simulation of solar absorption cooling system for a residential building in South Africa In: 22rd Domestic Use of Energy Conference (DUE), IEEE Xplore, (2014)

[22] Ellamla, H.R., Staffell, I., Bujlo, P., Pollet, Pasupathi, S.: Current status of fuel cell based combined heat and power systems for residential sector. J. Power Sources. 293, pp. 312-328, (2015)

[23]https://www.google.co.za/maps/place/Yangambi,+Democratic+Republic+of+the+Cong o/@0.8049361,24.4222205,14620m/data=!3m1!1e3!4m5!3m4!1s0x175695be5f7524eb:0x6 0a82b1d81067049!8m2!3d0.8070691!4d24.4529792?hl=en

24. http://dictionnaire.sensagent.leparisien.fr/YANGAMBI/fr-fr/

[25]https://www.google.co.za/maps/dir/Kisangani,+Orientale,+Democratic+Republic + of $+\mathrm{t}$ he+Congo/Yangambi,+Democratic+Republic+of+the+Congo/@0.6593595,24.543636,10z/ data $=! 3 \mathrm{~m} 1$ !4b1!4m13!4m12!1m5!1m1!1s0x1757a7333c4842bf:0xd0a33c1deddb9298!2m2 !1d25.2007728!2d0.5185303!1m5!1m1!1s0x175695be5f7524eb:0x60a82b1d81067049!2m 2!1d24.4529792!2d0.8070691?hl=en

[26]http://www.insel.eu/index.php?id $=21 \& \mathrm{~L}=1 \& \mathrm{tx}$ _srfeuserregister_pi1\%5Bcmd\%5D=cre ate\&tx_srfeuserregister_pi1\%5Btoken\%5D=42205e1c74285b9aa17a626a24224f45

[27] Longe, OM, Ouahada, K, Ferreira, HC.: Chinnappen S. Renewable energy sources microgrid design for rural area in South Africa. In Proc. IEEE ISGT- America (2014).

[28] Singh, A, Baredar, P, Gupta, B. :Techno-economic feasibility analysis of hydrogen fuel cell and solar photovoltaic hybrid renewable energy system for academic research building. Energy Conv. And Manag.145: pp. 398-414 (2017).

[29]https://energy.gov/sites/prod/files/2017/10/f37/fcto-progress-fact-sheet-august-

2017.pdf. (Accessed: 15 Febbruary 2017) 